\title{
T51D-0181: Origin and Age of the Researcher Ridge Seamount Chain (Central Atlantic)
}

\author{
Friday, 14 December 2018 \\ 08:00 - 12:20 \\ P Walter E Washington Convention Center - Hall A-C (Poster Hall)
}

Researcher Ridge (RR) is a $400 \mathrm{~km}$ long, WNW-ESE oriented chain of volcanic seamounts, located on $\sim 20$ to $40 \mathrm{Ma}$ old oceanic crust on the western flank of the Mid-Atlantic Ridge (MAR) at $\sim 15^{\circ} \mathrm{N}$. RR remained nearly unstudied, and thus its age and origin are currently unclear. At roughly the same latitude, the MAR axis is bathymetrically elevated and produces geochemically enriched lavas (the well-known $14^{\circ} \mathrm{N}$ MAR anomaly). This study presents ${ }^{40} \mathrm{Ar} /{ }^{39} \mathrm{Ar}$ age data, major and trace elements, and $\mathrm{Sr}-\mathrm{Nd}-\mathrm{Pb}-\mathrm{Hf}$ isotopic compositions of volcanic rocks dredged from several seamounts of the RR and along the MAR between $13-14^{\circ} \mathrm{N}$. The results reveal that RR lavas have geochemically enriched ocean island basalt (OIB) compositions $\left([\mathrm{La} / \mathrm{Sm}]_{\mathrm{N}}=1.7-5.0,[\mathrm{Ce} / \mathrm{Yb}]_{\mathrm{N}}=1.58-11.3\right)$ with isotopic signatures $\left({ }^{143} \mathrm{Nd} /{ }^{144} \mathrm{Nd}=0.51294-0.51316,{ }^{206} \mathrm{~Pb} /{ }^{204} \mathrm{~Pb}=19.14-19.93,{ }^{176} \mathrm{Hf} /{ }^{177} \mathrm{Hf}=0.28307-0.28312\right)$ trending to or overlapping the ubiquitous FOZO (Focal Zone, e.g., Hart et al., 1992, Science 256) mantle composition. Major and trace element characteristics denote that RR lavas formed by small degrees of melting from a deep source in the garnet stability field and experienced high pressure fractionation beneath a lithospheric lid. Although the sparseness of samples suitable for ${ }^{40} \mathrm{Ar} /{ }^{39} \mathrm{Ar}$ dating prevents establishing a clear age progression for the seamount chain, one well constrained basalt groundmass age of $28.75 \pm 0.14 \mathrm{Ma}(2 \sigma)$ for one seamount near the western end of RR indicates that this volcano formed $\sim 11 \mathrm{Ma}$ later than the underlying lithosphere. Taken together, $R R$ is interpreted as a hotspot track, albeit formed by a relatively weak melting anomaly. Compared to RR, the lavas from the $14^{\circ} \mathrm{N}$ MAR anomaly have slightly less enriched compositions, exhibiting enriched (E)-MORB compositions $\left([\mathrm{La} / \mathrm{Sm}]_{N}=1.81-2.29\right)$. Their isotopic ratios largely overlap with the RR compositions, thus suggesting a genetic relationship. We therefore propose that the enigmatic $14^{\circ} \mathrm{N}$ MAR anomaly is caused by deflection of upwelling RR plume material towards the approaching (westward migrating) MAR, causing the production of E-MORBs with nearly similar isotopic compositions to the RR lavas. Once the plume was captured by the spreading ridge, off-axis hotspot track volcanism ceased, resulting in a $300 \mathrm{~km}$ wide gap of seamount formation between the eastern end of RR and the MAR.

\section{Authors}

\section{Joerg Geldmacher}

GEOMAR Helmholtz Centre

for Ocean Research Kiel

Xiaojun Long

GEOMAR Helmholtz Centre for Ocean Research Kiel

Kaj Hoernle

GEOMAR Helmholtz Centre for Ocean Research Kiel

\section{Folkmar Hauff \\ GEOMAR}

Jo-Anne Wartho

GEOMAR Helmholtz Centre

for Ocean Research Kiel

Dieter Garbe-Schönberg

Institute of Geosciences

$\underline{\text { Ingo Grevemeyer }}$

GEOMAR

\section{$\underline{\text { Find Similar }}$}

\section{View Related Events}

Day: Friday, 14 December 2018 